\title{
Foliar release of dimethylsulfonioproprionate from Spartina alterniflora
}

\author{
J. Dean Pakulski ${ }^{1, *}$, R. P. Kiene ${ }^{2}$ \\ ${ }^{1}$ Department of Zoology and Institute of Ecology, University of Georgia, Athens, Georgia 30602, USA \\ ${ }^{2}$ University of Georgia Marine Science Institute, Sapelo Island, Georgia 31327, USA
}

\begin{abstract}
We report here that substantial quantities of dissolved dimethylsulfonioproprionate (DMSP) are released from live leaves of Spartina alterniflora in Georgia, USA salt marshes during tidal submergence. Mean monthly in situ foliar release rates varied from $0.092 \pm 0.050$ to $0.291 \pm 0.289 \mu \mathrm{mol}$ DMSP ( $g$ dry $w t)^{-1} h^{-1}$. Estimates of tidal release of DMSP from creekbank stands of S. alterniflora varied from $46 \pm 3$ to $684 \pm 411 \mu \mathrm{mol} \mathrm{DMSP} \mathrm{m} \mathrm{Dd}^{-1}$ with annual losses of $114 \mathrm{mmol} \mathrm{DMSP} \mathrm{m}^{-2} \mathrm{yr}^{-1}$ (3.6 $\left.\mathrm{g} \mathrm{S} \mathrm{m}^{-2} \mathrm{yr}^{-1}\right)$. Substantial quantities of DMSP accumulate on leaf surfaces. Extrafoliar DMSP accumulations on individual plants varied widely from undetectable to $>1 \mu \mathrm{mol}$ (g dry wt $)^{-1}$ Extrafoliar DMSP accumulations normalized to marsh surface area were generally $\leq 50 \mu \mathrm{mol} \mathrm{m}{ }^{-2}$ Additions of DMSP to salt marsh creek water resulted in a rapid increase in dimethylsulfide (DMS) production. Foliar release of DMSP into tidal water from $S$. alterniflora may contribute to the production of DMS and related compounds in southeastern S. alterniflora marshes.
\end{abstract}

\section{INTRODUCTION}

Biogenic emission of dimethylsulfide (DMS) is a major input of sulfur to the atmosphere (Andreae \& Raemodonk 1983, Andreae 1986). Salt marshes dominated by the cordgrass Spartina alterniflora exhibit high emission rates of DMS (Steudler \& Peterson 1984, Morrison \& Hines 1990). While the flux of DMS from salt marshes does not contribute greatly to the global flux of DMS to the atmosphere (Steudler \& Peterson 1984, Dacey et al. 1987), DMS emissions from these systems may have an impact on atmospheric sulfur and peroxy radical chemistry on a local or regional scale (Steudler \& Peterson 1984, Platt et al. 1990).

DMS is produced from the enzymatic cleavage of dimethylsulfonioproprionate (DMSP) yielding both DMS and acrylic acid (Cantoni \& Anderson 1956). Spartina alterniflora is unique among vascular salt marsh plants in eastern North America in its ability to accumulate DMSP in its tissues (Dacey et al, 1987). Cytoplasmic accumulation of DMSP and liberation of DMS has been reported from a number of halophytic

\footnotetext{
- Present address: Marine Science Institute, University of Texas, Port Aransas, Texas 78373, USA
}

plants including phytoplankton, macroalgae and vascular plants (Ackman et al. 1966, White 1982, Reed 1983, Dacey et al. 1987, Turner et al. 1988, Gibson et al. 1990, Karsten et al. 1990). While the precise role of DMSP in the physiology of $S$. alterniflora has not been determined, it is believed to serve an osmotic function in algae (Dickson et al. 1982, Vairavamurthy et al. 1985, Edwards et al. 1987) and may be accumulated by $S$. alterniflora and $S$. anglica tissues in response to increases in soil salinity or sulfide concentrations (van Diggelen et al. 1986, Dacey et al. 1987). Release of DMSP from marine emergent vascular macrophytes has not been investigated previously. We investigated foliar losses of DMSP from S. alterniflora during tidal submergence and the subsequent fate of this material in salt marsh tidal creeks.

\section{METHODS}

Sample collection. Samples were obtained from creekbank stands of Spartina alterniflora located along South End Creek, Sapelo Island, Georgia, USA. The creekbank area of southeastern marshes represents 8 to $18 \%$ of the total marsh area (Reimold et al. 1973, 
Dame et al. 1986). Creekbank stands of S. alterniflora at the study site were regularly submerged at high tide, whereas plants located on the high marsh were submerged less frequently and for comparatively shorter lengths of time.

Samples were collected bimonthly at high tides occurring at dawn, midday, dusk, and midnight. Release rates of DMSP were obtained by incubating live attached leaves exposed at high tide in sterile Whirl-Pac ${ }^{\text {TM }}$ bags containing $150 \mathrm{ml}$ freshly prepared $0.10 \mu \mathrm{m}$ filtered creek water (Gallagher et al. 1976. Pakulski 1986). Since bacterial assimilation of DMSP released from the plants during experimental incubations would influence estimates of net release, care was taken to minimize bacterial and chemical contamination of incubation solutions during preparation. Creek water for incubation solutions was collected on the flooding tide prior to sampling in acid-washed, combusted $\left(450^{\circ} \mathrm{C}, 4 \mathrm{~h}\right) 4 \mathrm{l}$ flasks and filtered within 5 min of collection through a combusted glass fiber filter (293 mm MSI) backed with a $0.22 \mu \mathrm{m}$ membrane (293 mm MSI Magna Nylon 66) enclosed in a plexiglass holder. The $0.22 \mu \mathrm{m}$ filtrate was subsequently passed through a separate $0.10 \mu \mathrm{m}$ membrane (293 mm MSI Magna Nylon 66). The first $1000 \mathrm{ml}$ of filtrate was discarded at each step during filtrate collection. Prior to assembly, filter holders were scrubbed with a weak detergent solution, rinsed with Milli-Q deionized water, washed briefly with a basic methanol solution ( $\mathrm{NaOH}$ saturated methanol mixed 1:1 with reagent grade methanol) and flushed again with Milli-Q water. Filters and assembled filter holders were briefly washed with $1 \mathrm{~N} \mathrm{HCl}$ and flushed again with copious amounts of Milli-Q deionized water.

Whirl-Pac bags containing $150 \mathrm{ml} 0.1 \mu \mathrm{m}$ filtrate were allowed to equilibrate to ambient creek water temperature in a bath prior to incubation experiments. Temperature changes in the bags were estimated by monitoring a separate Whirl-Pac bag containing $150 \mathrm{ml}$ filtered water and leaves over the course of the incubations. Throughout the study, temperatures in the bags varied $\pm 2.8^{\circ} \mathrm{C}(\mathrm{SE}=0.6, \mathrm{n}=16)$ from initial temperatures during incubation. Salinity of incubation solutions and creek water was measured with a refractometer at the time of collection. There was no difference in the salinity of the incubation solutions before or after filtration.

The amount of DMSP accumulated on the leaves prior to sampling (hereafter referred to as extrafoliar accumulations) was estimated by incubating unwiped leaves (5 randomly selected plants per sample date; 3 to 5 leaves per plant) in a prepared temperatureequilibrated Whirl-Pac bag for $60 \mathrm{~s}$. Leaves were subsequently removed from the bags, gently wiped clean with low leaching lint-free cleanroom wipes, carefully inserted into a fresh Whirl-Pac containing $150 \mathrm{ml} 0.10 \mu \mathrm{m}$ filtered water and incubated for $2 \mathrm{~h}$. Bags containing incubating leaves were supported on ring stands inserted into the sediment next to the plants and were exposed to ambient light regimes. Leaves remained attached to the plants during handling and incubation. Unpowdered polyethylene gloves were worn while handling plants.

Controls consisted of Whirl-Pac bags containing $150 \mathrm{ml} 0.1 \mu \mathrm{m}$ filtered creek water. Time zero (poisoned immediately with sodium azide, $20 \mathrm{mM}$ final concentration, and refrigerated at $4^{\circ} \mathrm{C}$ ) and final time (poisoned and refrigerated at the end of each incubation) controls were prepared for each plant sampled. Incubations were terminated by removing the leaves from the bags and poisoning the leachate with sodium azide (20 $\mathrm{mM}$ final concentration). The portions of the leaves immersed in the incubation solutions were excised and dried at $40^{\circ} \mathrm{C}$ for weight determinations.

DMSP analysis. Leachate samples were filtered through combusted glass fiber filters (Reeve Angel 934 $\mathrm{AH}$ ) at low vacuum $\left(<5 \mathrm{~mm} \mathrm{Hg}\right.$ ) and stored at $4{ }^{\circ} \mathrm{C}$ prior to DMSP analysis. DMSP was quantified by removing triplicate $2 \mathrm{ml}$ aliquots of filtered samples to $10 \mathrm{ml}$ serum vials and cleaving DMSP to DMS by the addition of $0.2 \mathrm{ml} 5 \mathrm{~N} \mathrm{NaOH}$. Vials were allowed to stand for at least $30 \mathrm{~min}$ after addition of base to allow DMS to equilibrate in the headspace. DMS evolved in the headspace was measured by removing $100 \mu \mathrm{l}$ of headspace gas with a gastight syringe and injecting the aliquot into a gas chromatograph equipped with a 2 m teflon Carbopack BHT column and a flamephotometric detector (White 1982, Kiene \& Service 1991). DMSP concentration in the headspace was assumed to be proportional to DMSP concentration in the sample solutions (White 1982, Vairavamurthy et al. 1985). DMSP for standards was obtained from Research Plus, Inc. The coefficient of variation for triplicate analyses was $<8 \%$. All values for release rates and extrafoliar accumulations were normalized to grams (dry wt) of leaf material.

Tidal release of DMSP from creekbank vegetation. To estimate tidal release of DSMP from the creekbank area of the marsh, a transect was established at the study site perpendicular to the creek extending from the edge of the vegetated zone of the marsh to the top of the levee. Stakes and twine were used to divide the vegetation along this transect into vertical sections $0.25 \mathrm{~m}$ in depth. Length of time each vertical section was submerged was determined for a spring and neap tide at each bimonthly sampling date. Vertical distribution of leaf biomass was estimated by harvesting live leaf material in each vertical section at 4 randomly selected $0.25 \mathrm{~m}^{2}$ plots along the transect. Biomass samples were washed and dried at $40^{\circ} \mathrm{C}$ before weight 
determinations. Submerged leaf biomass was determined by summing the quantity of biomass present in each vertical section submerged at high slack tide.

Tidal releases of DMSP were estimated by applying the mean foliar DMSP release rate (mean of 4 sampling dates per bimonthly interval) to the biomass and submergence time data obtained from each of the 4 plots along the transect. Tidal DMSP releases were then calculated as the mean ( $\pm 1 \mathrm{SE}$ ) from the 4 plots. We lacked data for 3 of the 4 sampling periods in March 1989. Mean monthly release rates and estimates of extrafoliar accumulations for March 1989 were conservatively estimated by assuming that values for the remaining 3 sampling periods were zero. Estimates of tidal release for March 1989 were calculated assuming a dusk high tide release rate of $1.16 \mu \mathrm{mol}$ DMSP (g dry wt) ${ }^{-1} \mathrm{~h}^{-1}$ (see 'Results', Fig. 2) and no release from the plants at the following dawn high tide.

Time course experiments. Time course experiments of DMSP release were conducted by incubating duplicate sets of plants in $150 \mathrm{ml} 0.10 \mu \mathrm{m}$ filtered creek water (as above) each with a separate time zero and final time control $(150 \mathrm{ml} 0.1 \mu \mathrm{m}$ filtered creek water) for $1,30,60,90$, and $180 \mathrm{~min}$ intervals. The amount of extrafoliar DMSP (time zero) was estimated by incubating unwiped leaves for $1 \mathrm{~min}$ in $150 \mathrm{ml} 0.10 \mu \mathrm{m}$ filtered creek water.

Exchange of DMSP from particulate material deposited on leaves. To determine whether DMSP was exchanged by particulate material or organisms attached to or deposited on Spartina alterniflora leaves, DMSP concentrations in suspensions of material obtained from creekbank plants was followed through time. Particulate material and extrafoliar DMSP was collected by vigorously shaking 5 plants for 1 min each in $2.5 \mathrm{l}$ freshly prepared $0.10 \mu \mathrm{m}$ filtered creek water. One hundred milliliter aliquots of the resulting seston suspension were dispensed to Whirl-Pac bags and incubated in the dark on a shaker at ambient creek water temperature $\left(31^{\circ} \mathrm{C}\right)$. Seston suspensions and controls were poisoned with sodium azide $(40 \mathrm{mM}$ final concentration) and frozen immediately upon termination of each incubation. Samples were subsequently filtered and assayed for DMSP as above.

Exchange of DMSP and other dissolved substances from Spartina alterniflora. In addition to the exchange of DMSP, foliar exchange of dissolved organic carbon (by persulfate oxidation; Menzel \& Vaccaro 1964), dissolved monomeric carbohydrates (by MBTH analysis; Johnson \& Sieburth 1977), ammonium (phenolhypochlorite reaction), and soluble reactive phosphorus (molybdate reaction) was investigated during May 1988. Five plants on 4 dates ( 20 plants total) were sampled using the methods outlined above. Uptake and release rates of these substances were determined for each plant and compared to the release rates of DMSP.

Scanning electron microscopy of leaf surfaces. Specimens of live Spartina alterniflora leaves were collected from the South End Creek marsh for SEM examination during early September 1986. Wiped and unwiped leaves were obtained from portions of plants regularly exposed or submerged at high tide. Sterilized (ethanol-rinsed and flamed) stainless steel scissors were used to excise leaf samples which were dropped directly into acid-washed and combusted glass scintillation vials containing $0.22 \mu \mathrm{m}$ filtered (Millex, Millipore Corp.), $2 \%$ phosphate buffered $(0.13 \mathrm{M}, \mathrm{pH}=7.6)$ glutaraldehyde solution without further handling. Leaf samples were dehydrated in a $0.22 \mu \mathrm{m}$ filtered, graded ethanol series (70 to $100 \%$ ) in a cleanroom. Samples were then critical point dried and sputter coated with gold/palladium prior to SEM examination.

DMS production from DMSP. The effect of DMSP additions on the rate of DMS production in the water column was examined by amending $250 \mathrm{ml}$ samples of unfiltered Duplin River (a large saline tidal creek adjacent to Sapelo Island) creek water with DMSP (20 $\mathrm{nM}$ final concentration) and incubating them in sealed teflon bottles at in situ temperature $\left(25^{\circ} \mathrm{C}\right)$. DMS concentrations were determined by gas stripping, cryotrapping and subsequent detection by flame photometric gas chromatography (Kiene \& Service 1991). Changes in the DMS concentration in the DMSP amended samples were compared to unamended creek water samples over time.

Dissolved and particulate DMSP concentrations in South End Creek and the Duplin River were determined by filtering freshly collected creek water through a combusted glass fiber filter (Gelman GF/F). Both the filter and the filtrate were treated with $\mathrm{NaOH}$ in serum vials sealed with teflon/silicone septa (Iverson et al. 1989). The resulting DMS was determined by gas stripping and cryotrapping as above.

\section{RESULTS}

\section{Foliar release rates and extrafoliar accumulations}

Concentrations of DMSP in leachate samples varied from undetectable to $>240 \mathrm{nmol} 150 \mathrm{ml}^{-1}$ of incubation solution. Examples of data from August 1988 are presented in Table 1. DMSP concentrations in the control solutions were below the detection limit (peak areas $<100)$ throughout the study. Mean monthly DMSP foliar release rates and extrafoliar accumulations varied from 0.092 to $0.291 \mu \mathrm{mol}$ DMSP (g dry wt) $)^{-1} \mathrm{~h}^{-1}$ and 0.159 to $19.39 \mu \mathrm{mol}(\mathrm{g} \text { dry } \mathrm{wt})^{-1}$ respectively (Fig. 1). Foliar DMSP release rates and extrafoliar 
Table 1 DMSP concentrations of incubation solutions, leaf weights, calculated foliar DMSP flux rates and extrafoliar accumulations from 10 August 1988. Samples were collected between 07:00 and 09:00 h. Alpha-numeric designations (TS 1 to 5) refer to individual plants. The quantity of extrafoliar DMSP accumulated on the leaves of each plant was estimated by incubating 3 to 5 unwiped leaves for $60 \mathrm{~s}$ in Whirlpac bags containing $150 \mathrm{ml} 0.1 \mu \mathrm{m}$ filtered creek water. DMSP release rates were estimated by incubating wiped leaves from the same plants for $120 \mathrm{~min}$ in a fresh solution of $0.1 \mu \mathrm{m}$ filtered creek water. DMSP concentration represents the quantity of DMSP present in the filtered creek water solutions after each incubation. Extrafoliar material is not included in estimates of flux rates

\begin{tabular}{|c|c|c|c|c|c|}
\hline \multirow[t]{2}{*}{ Plant } & \multirow{2}{*}{$\begin{array}{l}\text { Leaf weight } \\
\text { (g dry wt) }\end{array}$} & \multicolumn{2}{|c|}{60 s incubation } & \multicolumn{2}{|c|}{120 min incubation } \\
\hline & & $\begin{array}{c}\text { DMSP conc. }\left(\text { numol } 150 \mathrm{ml}^{-1}\right) \\
\text { mean } \pm \mathrm{SD}\end{array}$ & $\begin{array}{l}\text { Extrafoliar DMSP } \\
\left.\text { [nmol (g dry wt })^{-1}\right]\end{array}$ & $\begin{array}{c}\text { DMSP conc. }\left(\mathrm{nmol} 150 \mathrm{ml}^{-1}\right) \\
\text { mean } \pm \mathrm{SD}\end{array}$ & $\begin{array}{c}\text { DMSP release rate } \\
{\left[\mathrm{nmol}(\mathrm{g} \text { dry } \mathrm{wt})^{-1} \mathrm{~h}^{-1}\right]}\end{array}$ \\
\hline TS 1 & 0.30 & $42 \pm 2$ & 137 & $56 \pm 2$ & 93 \\
\hline TS 2 & 0.31 & $28 \pm 1$ & 92 & $75 \pm 3$ & 122 \\
\hline TS 3 & 0.12 & $19 \pm 1$ & 157 & $54 \pm 1$ & 224 \\
\hline TS 4 & 0.46 & $93 \pm 1$ & 201 & $56 \pm 3$ & 62 \\
\hline TS 5 & 0.49 & $65 \pm 5$ & 132 & $72 \pm 3$ & 73 \\
\hline
\end{tabular}

accumulations did not vary significantly $(p<0.05)$ over the day (Figs. $2 \& 3$ ).

Creek water salinities and temperatures at the study site varied from 25 to $34 \%$ and 9 to $34^{\circ} \mathrm{C}$ respectively, with the highest salinities and temperatures recorded during August 1988. Regression analyses revealed no significant relationships between release rates of DMSP and salinity $\left(r^{2}=0.04, p=0.43\right)$ or temperature $\left(\mathrm{r}^{2}=0.001, \mathrm{p}=0.93\right)$. There was also no significant relationship between extrafoliar accumulations and temperature $\left(\mathrm{r}^{2}=0.001, \mathrm{p}=0.95\right)$. There was, however, a significant relationship between extrafoliar accumulations and salinity during $1988\left(\mathrm{r}^{2}=0.36, \mathrm{p}=0.038\right)$ but none during 1989. Regression analyses further revealed a weak but significant relationship $\left(r^{2}=0.11\right.$, $p=0.014, n=56$ ) between DMSP loss rates and extrafoliar DMSP accumulations on individual plants during 1988 but no significant relationship during 1989. During 1988, $100 \%$ of the plants sampled exhibited DMSP release while only 40 to $80 \%$ of the plants exhibited release during 1989.

\section{Tidal release rates and area normalized extrafoliar accumulations}

Tidal DMSP release rates were highest in early spring (mean $\pm 1 \mathrm{SE}, 684 \pm 443 \mu \mathrm{mol} \mathrm{m} \mathrm{m}^{-2} \mathrm{~d}^{-1}$ ) and were relatively constant (mean $\pm 1 \mathrm{SE}, 116 \pm 31 \mu \mathrm{mol}$ $\mathrm{m}^{-2} \mathrm{~d}^{-1}$ ) throughout the rest of the growing season (Fig. 4a). Release rates for March 1988 were calculated conservatively. If release rates observed for the dusk sampling period in March 1988 were representative for that season, however, tidal. releases would have been ca $1100 \mu \mathrm{mol} \mathrm{m} \mathrm{m}^{-2} \mathrm{~d}^{-1}$. Assuming that the bimonthly tidal DMSP rates (the mean of neap and spring tide rates in Fig. 4) were representative for the interval between sampling dates, we estimate annual tidal DMSP release to be 78 to $166 \mathrm{mmol} \mathrm{m}^{-2} \mathrm{yr}^{-1}$ (2.5 to $\left.4.7 \mathrm{~g} \mathrm{~S} \mathrm{~m}^{-2} \mathrm{yr}^{-1}\right)$ with a median estimate of $114 \mathrm{mmol}$ $\mathrm{m}^{-2} \mathrm{yr}^{-1}\left(3.6 \mathrm{~g} \mathrm{~S} \mathrm{~m}^{-2} \mathrm{yr}^{-1}\right)$.
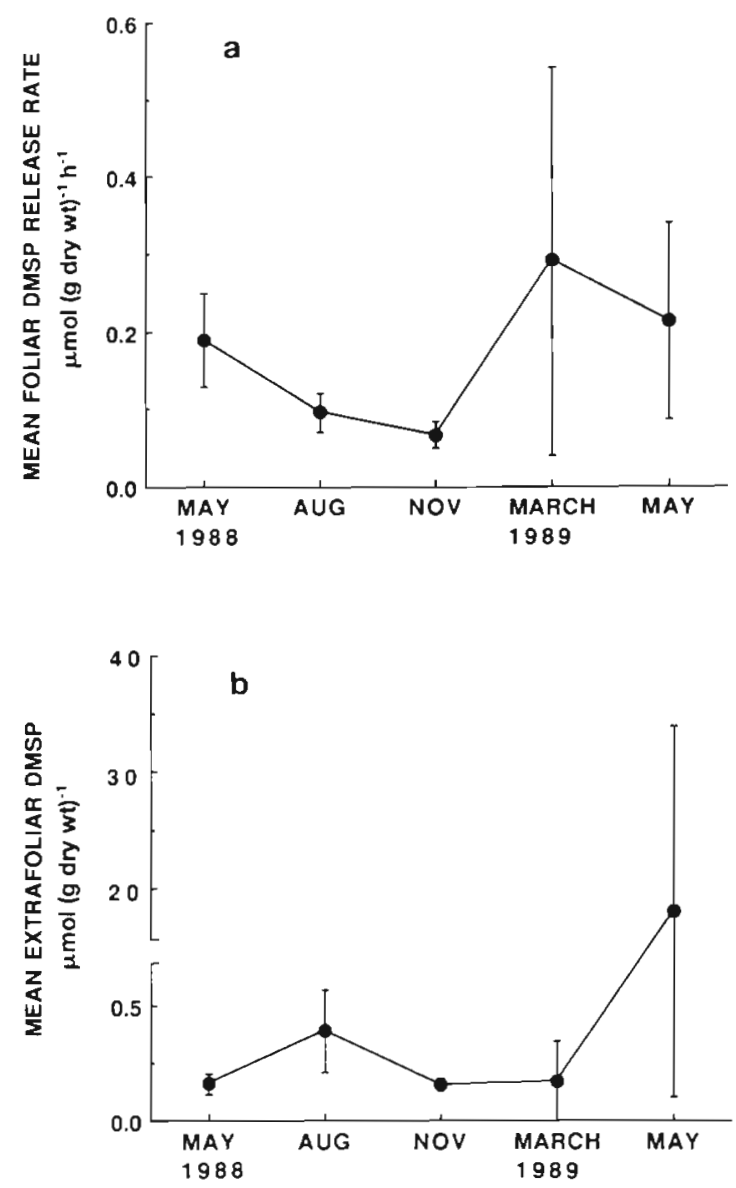

Fig. 1. Spartina alterniflora. Seasonal variation in (a) foliar DMSP release rates by live leaves and (b) extrafoliar DMSP accumulations. Each point represents mean ( $\pm 1 \mathrm{SE}$ ) of values from 4 dates sampled at each bimonthly sampling period. Note scale break in $y$-axis 

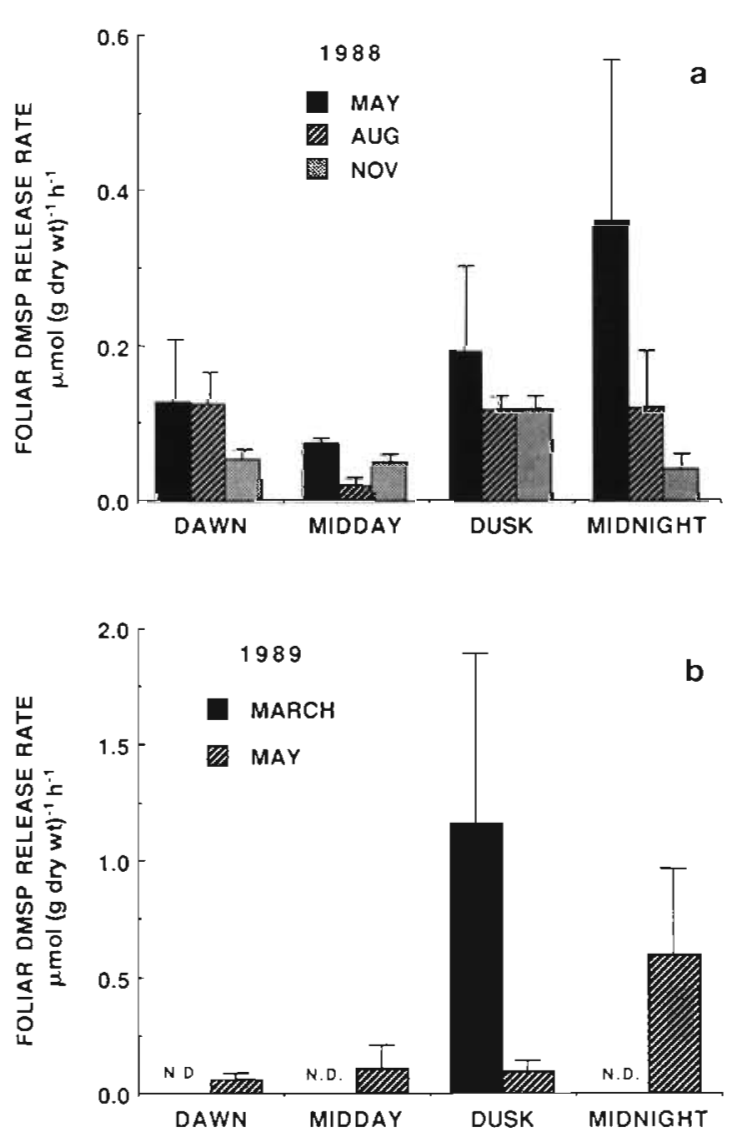

Fig. 2. Spartina alterniflora. Diel variation in foliar DMSP release rates in (a) 1988 and (b) 1989. Each bar represents the mean ( $\pm 1 \mathrm{SE}$ ) release rate from 5 plants sampled at each period of the day. N.D.: no data

Area normalized estimates of extrafoliar DMSP accumulations varied from 37 to $50 \mu \mathrm{mol} \mathrm{m} \mathrm{m}^{-2}$ through 1988 and early 1989 (Fig. 4b). During May 1989, $20 \%$ of the plants sampled had high $[1$ to $330 \mu \mathrm{mol}$ (g dry $w t)^{-1}$ ] leaf weight normalized extrafoliar DMSP accumulation values. This was reflected in high values of area normalized estimates of extrafoliar DMSP accumulations for that period. Our estimates of tidal release did not include tidal removal of extrafoliar DMSP.

\section{Time course of foliar release and uptake}

Time course experiments revealed that the release of DMSP from the plants is a 2-step process with a rapid removal of extrafoliar material (inferred from $60 \mathrm{~s}$ washes) and a low rate of release from the leaves thereafter (Fig. 5a). After a 2 to $4 \mathrm{~h}$ lag, DMSP concentrations in suspensions of particulate material obtained from leaves dropped dramatically (Fig. 5b). DMSP concentrations in unpoisoned solutions were at the limit of detection ( 3 to $5 \mathrm{nM}$ ) at the end of the $6 \mathrm{~h}$ incubation.
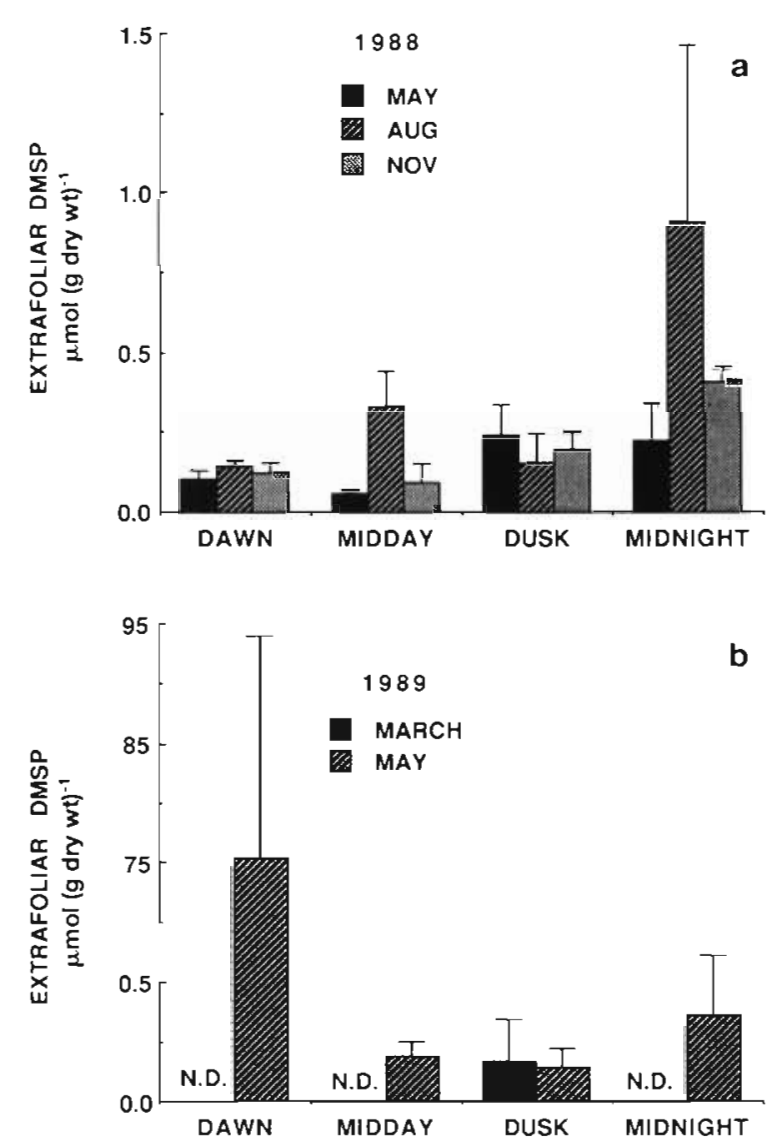

Fig. 3. Spartina alterniflora. Diel variation in extrafoliar DMSP accumulations in (a) 1988 and (b) 1989. Each bar represents the mean ( $\pm 1 \mathrm{SE}$ ) accumulation from 5 plants sampled at each period of the day. Note scale break in y-axis

\section{DMS production from DMSP}

Experimental additions of dissolved DMSP to tidal creek water suggested that dissolved DMSP was rapidly metabolized to DMS by microbial activity (Fig. 6). DMS concentrations in DMSP amended creek water increased dramatically and without a time lag. From this experiment and others (Kiene \& Service 1991) we estimate turnover time on the order of ca $6 \mathrm{~h}$ or less for dissolved DMSP in the estuarine waters adjacent to Sapelo Island.

\section{Relationship between release of DMSP and other dissolved substances from Spartina alterniflora}

DMSP appears to be a small but significant component of the dissolved organic carbon (DOC) released from the plants. DMSP carbon release rates recorded during May 1988 [9.2 $\mu \mathrm{g} \mathrm{C}(\mathrm{g} \text { dry } w \mathrm{t})^{-1} \mathrm{~h}^{-1}$ ] were equivalent to $5 \%$ of the DOC [198 $\mu \mathrm{g} \mathrm{C} \mathrm{(g} \mathrm{dry}$ $w t^{-1} h^{-1}$ ] and $9 \%$ of the dissolved monosaccharide [108 $\mu \mathrm{g} \mathrm{C}(\mathrm{g} \text { dry } w t)^{-1} \mathrm{~h}^{-1}$ ] release rates for the same 

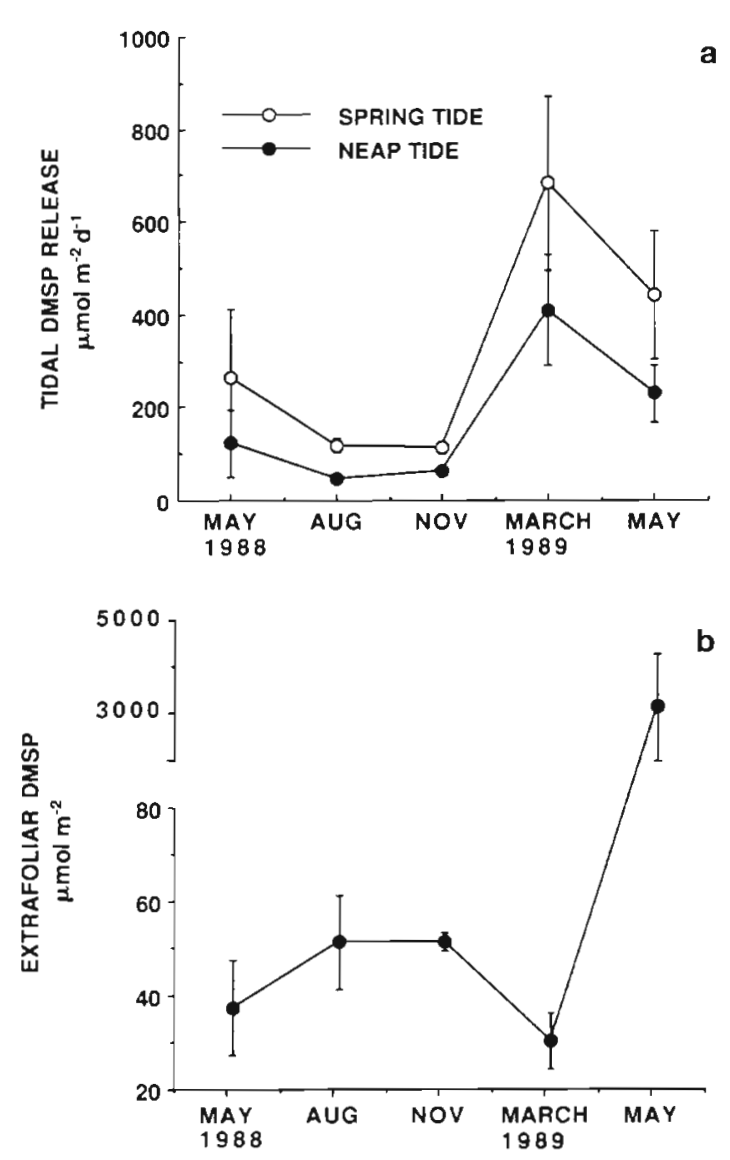

Fig. 4. Spartina alterniflora. Seasonal pattern of (a) area normalized tidal DMSP release 1988-89 and (b) area normalized extrafoliar DMSP accumulations 1988-89. Each point represents the mean value $( \pm 1 \mathrm{SE}$ ) for each date. Note break in $Y$-axis

period. Statistical analyses, however, revealed no significant correlations between release rates of DMSP and those of DOC $\{r=0.28, p=0.23)$, dissolved monosaccharides $(r=0.10, p=0.62)$, soluble reactive phosphate $(\mathrm{r}=0.41, \mathrm{p}=0.07)$ or ammonium $(\mathrm{r}=0.023$, $\mathrm{p}=0.53$ ) during the period investigated. Annual releases of DMSP as carbon were $6.9 \mathrm{~g} \mathrm{C} \mathrm{m}^{-2} \mathrm{yr}^{-1}$. DMSP carbon releases were similar to the lower estimates of DOC losses from Spartina alterniflora reported from Georgia marshes (6 to $150 \mathrm{~g} \mathrm{C} \mathrm{m}^{-2} \mathrm{yr}^{-1}$; Gallagher et al. 1976, Turner 1978, Pakulski 1986).

\section{Scanning electron microscopy of leaf surfaces}

SEM examination of living leaves obtained from both high and low marsh plants during late summer revealed a remarkably sparse epiphyte community consisting only of very small, widely scattered masses of fungal hyphae. No recognizable bacteria or intact microalgae were observed on any of the specimens examined. Portions of leaves regularly exposed at high
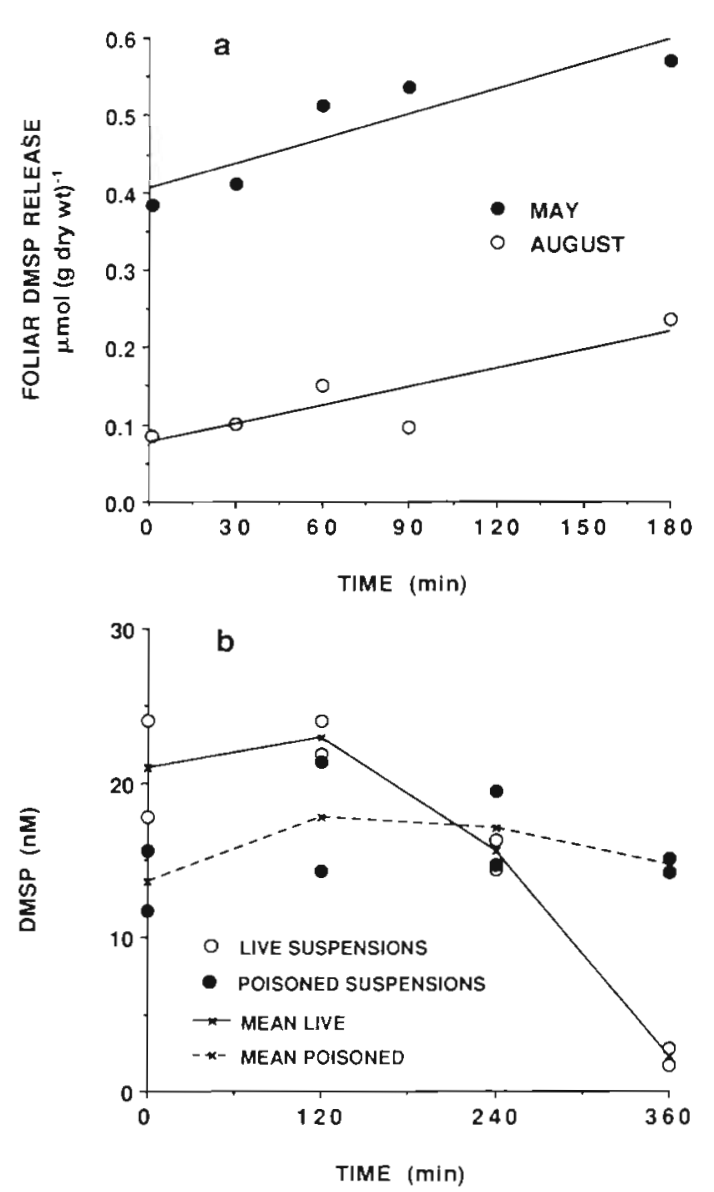

Fig. 5. Spartina alterniflora. (a) Time course of DMSP release in May and August 1988. Time zero values represent the amount of DMSP accumulated on leaves at time of sampling Each point represents the mean value obtained from 2 plants plus the time zero value. (b) Time course of DMSP concentrations (mean of 2 bags) in suspensions of particulate material obtained from 5 plants in August 1988

tide were relatively free of both epiphytes and nonliving particulate material (Fig. 7). Leaves regularly submerged at high tide were encrusted with a coating of clay particles and diatom frustule fragments (Fig. 8a). Examination of wiped and unwiped leaves revealed no visible damage to the leaves as the result of handling and demonstrated that wiping was effective in removing much of the particulate material adhering to the leaves (Fig. 8b).

\section{DISCUSSION}

Tidal release of DMSP from Spartina alterniflora and its fate in adjacent waters

Biogenic tertiary sulfonium compounds such as DMSP are important precursors of DMS and related 


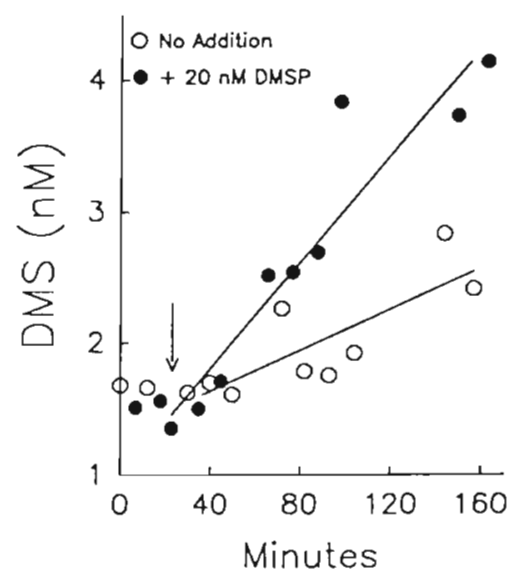

Fig. 6. Time course of DMS production in ( ) DMSP amended (20 nM final concentration) and (O) unamended Duplin River water. Lines indicate least squares fit using time of DMSP addition as time zero. Regression for unamended water: $y=0.00778 x+1, r^{2}=0.65, n=9$. Regression for DMSP amended treatment: $y=0.0203 x+0.993, r^{2}=0.99, n=9$

substances (Taylor \& Kiene 1989, Kiene \& Service 1991). Annual tidal releases of dissolved DMSP from the marsh site sampled in the present study $13.6 \mathrm{~g} \mathrm{~S}$ $\mathrm{m}^{-2} \mathrm{yr}^{-1}$ ) were several times the annual gaseous flux of DMS, methyl mercaptan, carbon disulfide, and carbonyl sulfide reported from a number of salt marshes (Adams et al. 1981, Aneja et al. 1982, Steudler \& Peterson 1984, 1985). Our data suggest that the release of dissolved DMSP from Spartina alterniflora during tidal submergence may be an important source of organic sulfur compounds in southeastern salt marsh tidal creeks. The turnover time of dissolved DMSP in the waters adjacent to Sapelo Island, however, is probably less than 1 tidal cycle (Kiene \& Service 1991). Thus, despite the relatively large flux of DMSP from the plants, the amount of DMSP exported to adjacent open waters may not be large due to its rapid turnover in the water column.

While only small quantities of DMSP may be exported from the marsh, experimental additions of dissolved DMSP to tidal creek water indicate that DMSP was rapidly metabolized to DMS. Less than one third of the DMSP metabolized in estuarine waters around Sapelo Island, however, is accounted for by DMS production alone (Kiene \& Service 1991). Acrylic acid and substantial quantities of yet unidentified substances are apparently produced from the metabolism of DMSP. Tidal losses of DMSP from Spartina alterniflora marshes could, therefore, contribute significantly to production (and possible export) of DMS, acrylic acid and other metabolites of DMSP in tidal creek waters.

Considering the amount of extrafoliar DMSP accumulated on the leaves, throughfall (i.e. removal of extrafoliar substances by rainfall or dewfall) of DMSP may supply substantial quantities of this substance to the sediment surface. Some extrafoliar DMSP is undoubtedly removed during tidal submergence as well. However, without detailed information concerning rates of accumulation of extrafoliar DMSP and subsequent removal, it is difficult to accurately estimate the amount of DMSP released from the plants by either mechanism. We have chosen not to include these losses in our estimates of annual DMSP release; our estimates of annual release, therefore, are probably conservative.

\section{Mechanisms of DMSP release from Spartina alterniflora}

Data revealed little that would suggest any possible mechanism(s) for the release of DMSP from the plants. The absence of any significant diel variation in DMSP release rates suggests that DMSP release may not be directly linked to photosynthesis The lack of any significant relationships between DMSP release rates and those of monosaccharides and DOC during May 1988 further suggests that DMSP release may not be directly linked to carbon metabolism. The relationships between salinity and tissue DMSP concentrations Spartina spp. and their relationships to the release of DMSP from these plants are not entirely clear. Van Diggelen et al (1986) reported that tissue DMSP concentrations in hydroponically grown $S$, anglica were independent of salinity. In contrast, Dacey et al. (1987) reported a positive relationship between marsh soil pore water salinity and leaf DMSP concentrations in $S$ alterniflora. Other data reported by Dacey et al. (1987) suggests that the nutritional status of the plants, particularly with respect to nitrogen, may play an equal or greater role in the physiology of DMSP production than salinity. We did not measure pore water salinity at our sampling site. However, the weak $(0.1>p>0.05)$ statistical relationship between DMSP and soluble reactive phosphorus release rates and the lack of a relationship between release rates and creek water salinity suggest that DMSP release may not be related to salt excretion by the plants.

Dacey et al. (1987) reported that DMS release from Spartina alterniflora coincided with the late season senescence of the leaves. The seasonal pattern of DMSP release in the present study suggests that release of DMSP coincides with the period of rapid growth in the spring and not senescence. Dacey \& Wakeham (1983) have also suggested that grazing zooplankton may be responsible for the liberation of DMS and DMSP from microalgae in seawater. It is 

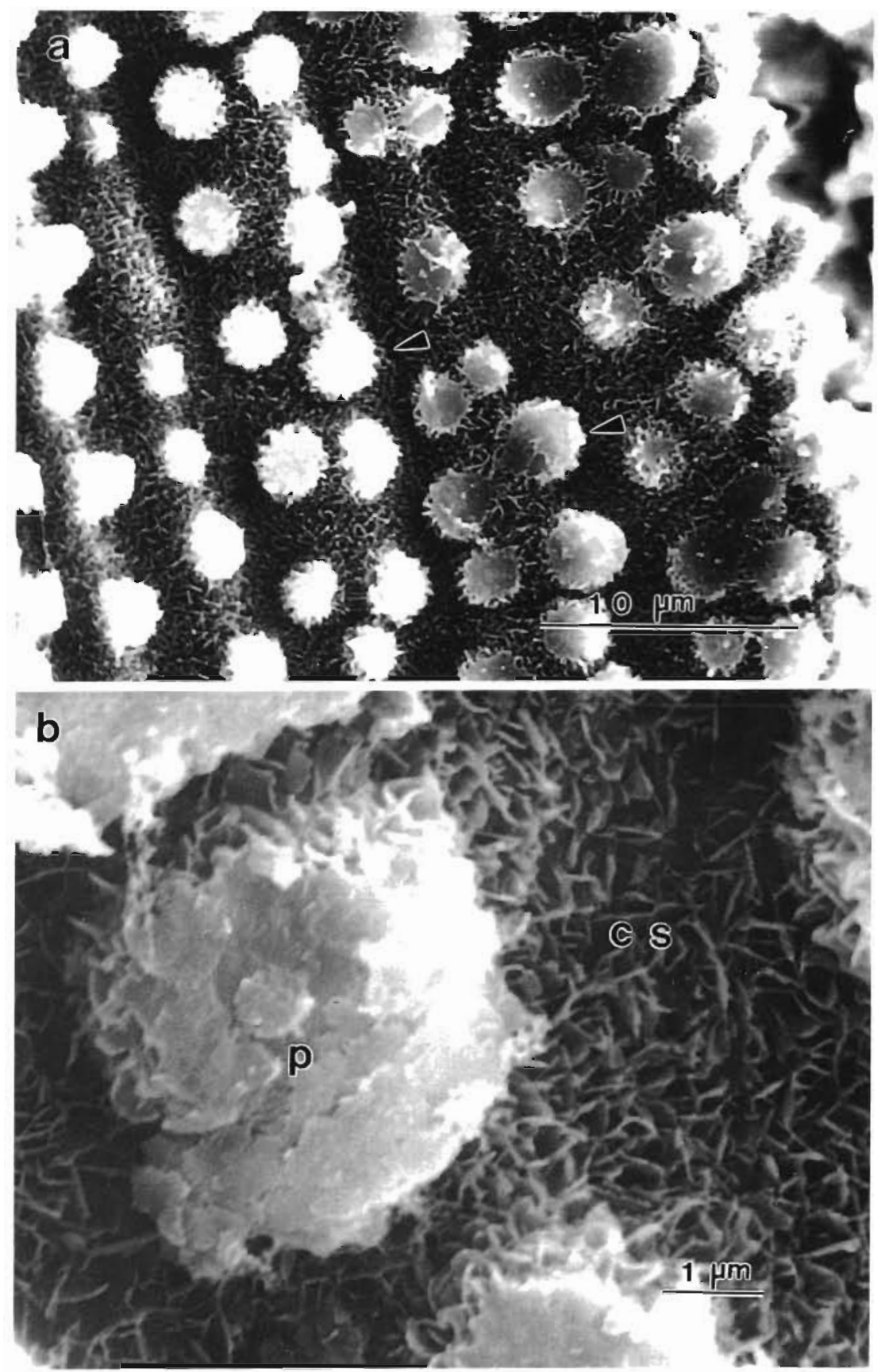

Fig. 7. Spartina alterniflora. SEM photomicrographs of leaf surface regularly exposed at high tide. (a) Adaxial ridges with papillae (arrows). $5400 \times$ (b) Adaxial surface with detail of papillae (P) and cuticle surface (CS). $14000 \times$ Note the lack of attached organisms

not readily apparent, however, whether herbivory was responsible for the release of DMSP observed in the present study. Pakulski (unpubl.) hypothesized that foliar release of ammonium by $S$. alterniflora may be related to tissue damage caused by grazing insects. Extrafoliar accumulations and releases of ammonium from the plants sampled in the present study peaked in August 1988 and coincided with a dramatic drop in leaf biomass. However, there was only a slight increase in extrafoliar DMSP accumulations during August 1988 and no corresponding increase in DMSP release rates. Based on the evidence at hand, we cannot conclude that insect grazing was responsible for the release of DMSP from the plants.

\section{Epiphytes and the release of DMSP from Spartina alterniflora}

The absence of an extensive epiphyte community on live Spartina alterniflora leaves is remarkable considering the dense community of fungi and algae that 


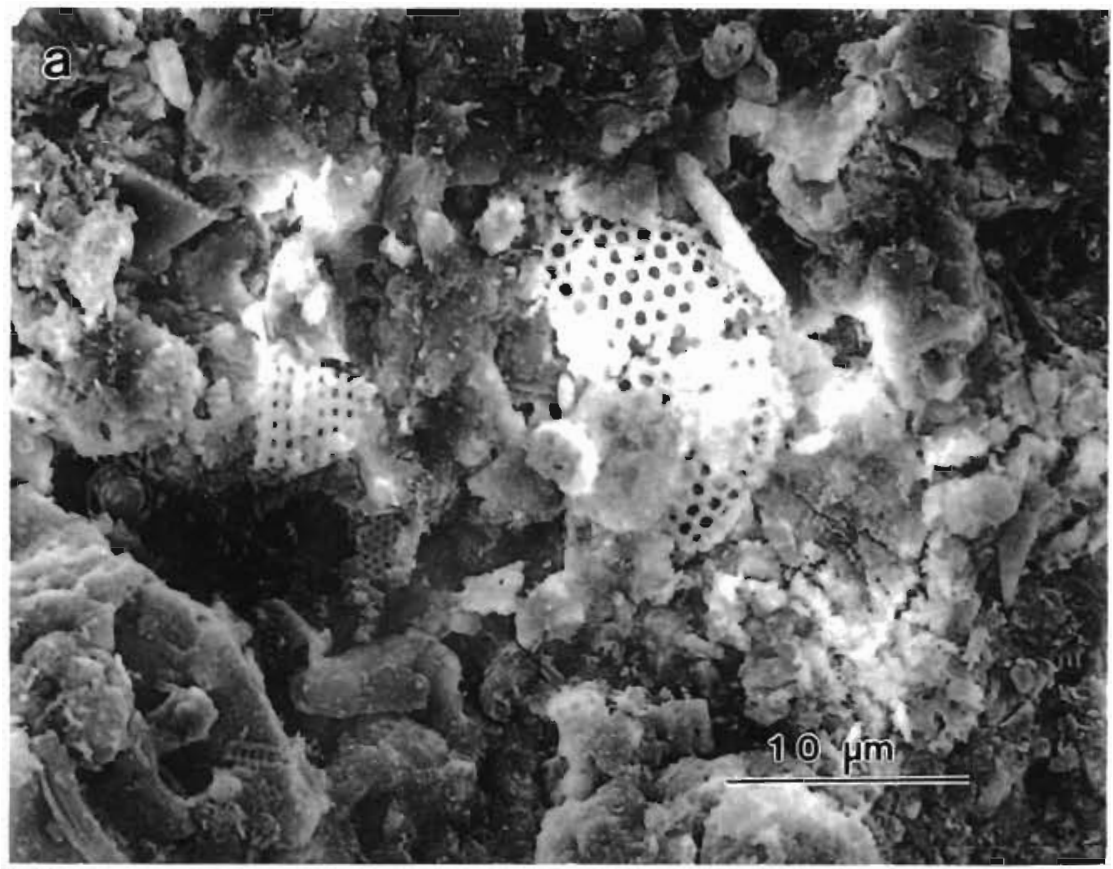

Fig. 8. Spartina alterniflora. SEM photomicrographs of the effect of wiping on adaxial leaf surfaces regularly submerged at high tide. (a) Unwiped surface. Note numerous fragments of diatom frustules. $2400 \times$. (b) Wiped surface. $2400 \times$

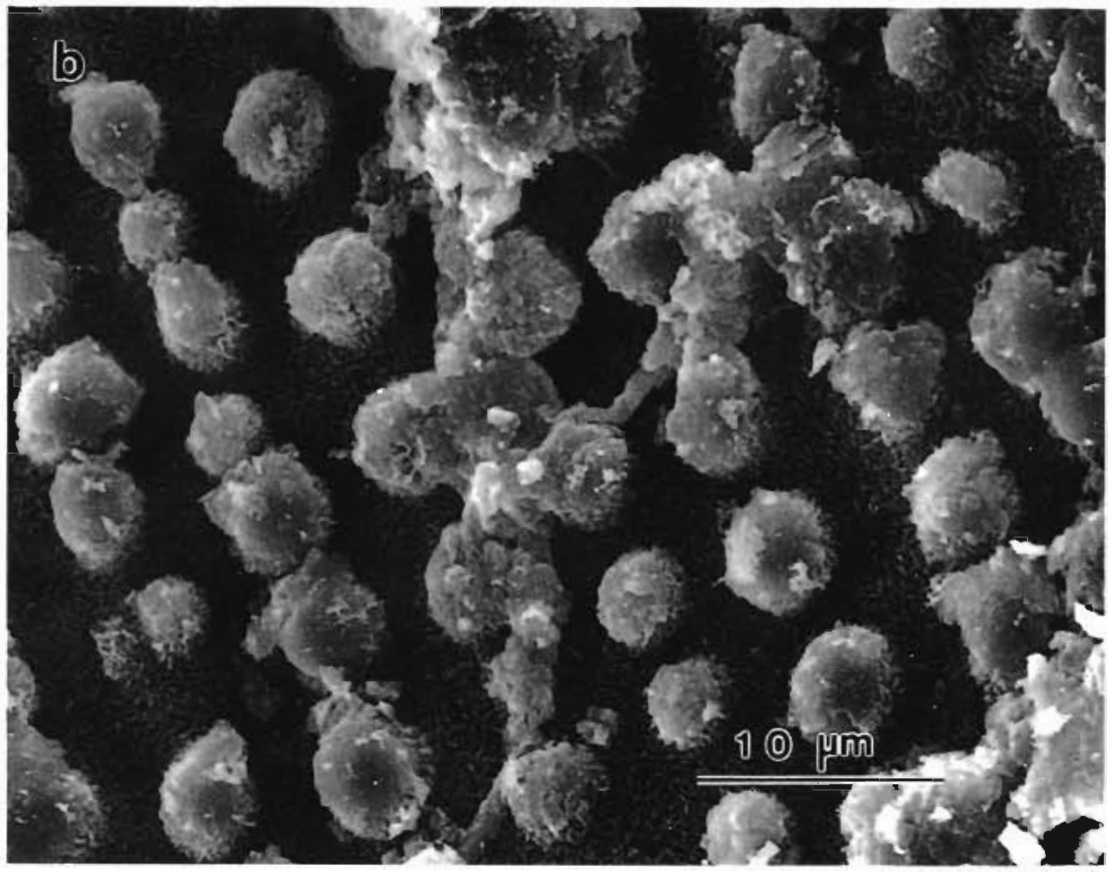

exists on the standing dead plants (Newell \& Hicks 1982, Stowe 1982, Fallon et al. 1985). Sieburth et al. (1974) have also reported a similar lack of microalgae and bacteria from SEM examinations of live leaves of S. alterniflora from a New England marsh.

Dame et al. (1991) have suggested that epiphytes of Spartina alterniflora intercept and assimilate dissolved organic carbon released from the plants. There is little evidence from the present study to suggest that epiphytes mediate the release of DMSP from the plants. Time course experiments demonstrated that there was a continuous release of DMSP from the plants and no apparent change in the rate of that release over a $3 \mathrm{~h}$ period (Fig. 5a). DMSP concentrations in suspensions of the particulate material removed from $S$. alterniflora leaves, however, exhibited little change over the first $2 \mathrm{~h}$ of incubation and declined thereafter (Fig. 5b). The results of the time course and leaf particulate material experiments and evidence from SEM examination of the leaves suggest that while some viable and metabolically active microbial consumers of DMSP (presumably bacteria) are present on the leaves, they do 
not exist in great numbers and may not greatly influence the release of DMSP from the plants. Finally, the data suggests that the DMSP released during leaf incubations and accumulated on the leaf surfaces originates from the plants themselves and not from epiphytes, tidally deposited organisms or particulate material.

While microorganisms present on leaf surfaces may not affect the release of dissolved DMSP during tidal submergence, microbial metabolism of extrafoliar DMSP may enhance the release of DMS from the plants. Dacey et al. (1987) have suggested that DMS emissions from a New England salt marsh originate from the physiological degradation of DMSP within leaves of Spartina alternifiora. DMS emissions from S. alterniflora reported by Dacey et al. (1987) required a daily turnover of $0.8 \%$ of the leaf tissue DMSP. The midsummer above-ground tissue inventory of DMSP in the tall $S$. alterniflora zone at Sapelo Island is ca $90 \mathrm{mmol} \mathrm{m}^{-2}$ (R. Kiene unpubl.). Extrafoliar DMSP accumulations (excluding high May 1989 values) were equivalent to ca $0.1 \%$ of the tissue DMSP inventory while foliar losses would represent a turnover of 0.1 to $1.4 \%$ of the tissue DMSP $\mathrm{d}^{-1}$. The turnover time of extrafoliar DMSP is not known. However, if extrafoliar DMSP is metabolized to DMS as the result of microbial activity during periods of tidal exposure, as suggested by the incubation of particulate material removed from the leaves, DMS production from extrafoliar DMSP

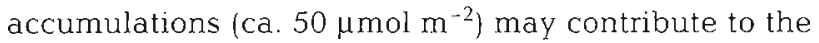

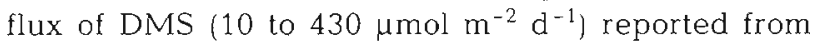
other salt marshes (Adams et al. 1981, Aneja et al. 1982, Steudler \& Peterson 1984, Morrison \& Hines $1990)$.

\section{Relationships between DMSP release rates and extrafoliar accumulations}

There was only a weak relationship between DMSP release rates and extrafoliar accumulations. The amount of extrafoliar DMSP accumulated on the leaves may be influenced by a variety of factors. Meteorological conditions, such as the frequency and intensity of rain or dewfall, and microbial (and possibly insect) activity may influence the quantity of material on the leaves to a greater extent than potential supply of DMSP to the leaf surface from internal pools.

There may also be differences in the rate of accumulation of extrafoliar DMSP and rates of submerged release. Turner (1978) reported that submerged release rates of DOC from Spartina alterniflora were substantially greater than accumulation rates or 'slow release' of DOC on leaf surfaces during periods of tidal exposure. Differences in the rates of release and accumulation of
DMSP by individual plants may also account for the weak statistical relationship between the 2 processes.

While regression analysis revealed a weak positive relationship between DMSP Ioss rates and extrafoliar DMSP accumulated on individual leaves during 1988. a comparison of the seasonal trends in area normalized release rates and extrafoliar accumulations (Fig. 6) appear to suggest an inverse relationship between tidal losses and area normalized extrafoliar accumulations. The trends in these 2 sets of data are due to seasonal changes in the amount of leaf material submerged at high tide and the total amount of leaf biomass present and are not the result of any interaction between release rates and accumulations. During early spring, high foliar DMSP release rates combined with a relatively large amount of submerged leaf biomass associated with the young shoots resulted in larger estimates of tidal losses than during the summer months. The increase in total leaf biomass of the maturing shoots, however, resulted in an increase in the total amount of extrafoliar DMSP accumulated on the leaves per unit area.

While foliar release of DMSP from Spartina alterniflora may be an important source of this compound within the marsh-estuarine system, the relative importance of DMSP originating from marsh soil pore waters, edaphic algae, phytoplankton and Spartina detritus to the pool of dissolved DMSP in marsh tidal waters has not been established. Furthermore, since the production and consumption of DMS in the water column are tightly coupled (Kiene \& Bates 1990, Kiene \& Service 1991), the release of DMSP from $S$. alterniflora during tidal submergence may not necessarily enhance emissions of DMS from the water column to the atmosphere. The contribution of DMS originating from the microbial metabolism of extrafoliar DMSP to the total flux of DMS from S. alterniflora, however, has not been evaluated, and may prove to have a greater impact on the flux of DMS from the marsh than submerged releases of DMSP to tidal waters.

Acknowledgements. This work was supported by the National Science Foundation grant OC.E-88-17442 to R.P.K., a doctoral dissertation improvement grant OCE 85-14540 to L. R. Pomeroy and J.D.P., and the Lniversity of Georgia Marine Institute. J.D.P. also thanks L. R. Pomeroy and W. J. Wiebe as well as the employees and staff of the University of Georgia Marine Institute, especially J. Alberts, and $M$. Price, for their assistance and support during this unvestigation.

\section{LITERATURE CITED}

Ackman, R. G., Tocher, C. S., MacLachlan, J. (1966). The occurrence of dimethyl- $\beta$-propriothetin in marine phytoplankton. Fish. Res. Bd Can. 23: 357-364 
Adams, D. F., Farwell, S. O., Robinson, E., Pack, M. R., Bamesberger, W. L. (1981). Biogenic sulfur source strengths. Environ. Scl. Technol. 32: 803-807

Andreae, M. O. (1986). The role of air-sea exchange in geochemical cycling. D. Reidel Publishing Co., New York

Andrede, M. O., Raemdonck, H. (1983). Dimethyl sulfide in the surface ocean and the marine atmosphere: a global view. Science $221744-747$

Aneja, V. P., Aneja, A. P., Adams, D. F. (1982). Biogenic sulfur compounds and the global sulfur cycle. J. Air Pollut. Control. Assoc. 32: 803-807

Cantoni, G. L., Anderson, D. G. (1956). Enzymatic cleavage of dimethylpropriothetin by Polysiphonia lanosa. J. Biol. Chem. 222: 171-177

Dacey, J. W. H., King, G. M., Wakeham, S. G. (1987). Factors controlling emission of dimethylsulfide from salt marshes. Nature, Lond. 330: 643-647

Dacey, J. W. H., Wakeham, S. G. (1983). Oceanic dimethylsulfide: production during zooplankton grazing on phytoplankton. Science 233: 1314-1316

Dame, R. T., Chzranowski, T., Bildstein, K., Kjervfer, B., McKellar, H., Nelson, D., Spurrier, J., Stancyk, S. Stevenson, H., Vernberg, J., Zingmark, R. (1986). The outwelling hypothesis and North Inlet, South Carolina. Mar. Ecol. Prog. Ser. 33: 217-229

Dame, R. T., Spurrier, J Williams, T M., Kjervfer, B., Zingmark, R., Wolaver, T G., Chzranowski, T., McKellar, H., Vernberg, F. J. (1991). Annual material processing by a salt marsh-estuarine basin in South Carolina, USA. Mar. Ecol. Prog. Ser. 72: 153-166

Dickson, D. M., Wyn Jones, R. G., Davenport, J. (1982). Osmotic adaptation in Ulva lacfuca under fluctuating salinity regimes. Planta 150: 158-165

Edwards, D. M., Reed, R. H., Chudek, J A., Foster, R., Stewart, W. D. P. (1987). Organic solute accumulation in osmotically-stressed Enteromorpha intestinalis. Mar. Biol. 95: $583-592$

Fallon, R. D., Newell, S. Y., Groene, L. C (1985). Phylloplane algae of standing dead Spartina alterniflora. Mar. Biol. 90: $121-127$

Gallagher J. L., Pfeiffer, W. J., Pomeroy, L. R. (1976). Leaching and microbial utilization of dissolved organic carbon by Spartina alterniflora. Estuar. coast. mar Sci. 4: $467-471$

Gibson, J. A. E., Garrick, R. C., Burton, H. R., McTaggart, A. R. (1990). Dimethylsulfide and the alga Phaeocystis pouchetii in antarctic coastal waters. Mar. Biol. 104: 339-346

lverson, R. L., Nearhoof, F. L., Andreae, M. O. (1989). Production of dimethylsulfonium proprionate and dimethylsulfide by phytoplankton in estuarine and coastal waters. Limnol. Oceanogr. 34: 53-67

Johnson, M. J., Sieburth, J. McN. (1977). Dissolved carbohydrates in seawater. 1. A precise spectrophotometric analysis for monosaccharides. Mar. Chem. 5: 1-13

Karsten, U., Wiencke, C., Kirst, G. O. (1990). The $\beta$-dimethylsulphonioproprionate (DMSP) content of macroalgae from Antarctica and southern Chile. Bot. Mar. 33: 143-146

Kiene, R. P., Service, S. (1991). Decomposition of dissolved DMSP and DMS in estuarine waters: dependence on temperature and substrate concentration. Mar. Ecol. Prog. Ser. 76: $1-11$
Kiene, R. P., Bates, T. S. (1990). Biological removal of dimethyl sulfide from sea water. Nature, Lond. 345: 702-70

Menzel. D. W., Vaccaro, R. F. (1964). The measurement of dissolved organic and particulate organic carbon in seawater. Limnol. Oceanogr. 9: 1.38-142

Morrison, M. C. Hines, M. E. (1990). The variability of bıogenic sulfur flux from a temperate salt marsh on short time and space scales. Atmos. Environ. 24: 1771-1779

Newell, S. Y., Hicks, R. E. (1982). Direct-count estimates of fungal and bacterial biovolume in dead leaves of smooth cordgrass (Spartina alterniflora Loisel.) Estuaries 5: $264-260$

Pakulski, J. D. (1986). The release of reducing sugars and dissolved organic carbon from Spartina alterniflora in a Georgia salt marsh. Estuar coast. mar. Sci. 22: 385-394

Platt, U., LeBras, G., Poulet, G., Burrows, J. P., Moortgat, G (1990). Peroxy radicals from night-time reaction with organic compounds. Nature, Lond. 348: 147-149

Reed, R. H. (1983). Measurement and osmotic significance of $\beta$-dimethylsulphonioproprionate in marine macroalgae Mar. Biol. Lett. 4: 173-181

Reimold, R. J., Gallagher, J. L., Thompson, D. E. (1973) Remote sensing of a tidal marsh. Photogramm. Eng. 39 $477-488$

Sieburth, J. McN., Brooks, R. D., Gessner, R. V., Thomas, C. D. Tootle, J. L. (1974). Microbial colonization of marine plant surfaces by scanning electron microscopy. In Colwell, R. D. Morita, R. Y (eds.) Effect of ocean environment on microbial activity. Univ. Park Press, p. $418-432$

Stowe, W. C. (1982). Diatoms epiphytic on the emergent grass Spartina alterniflora in a Louisiana salt marsh. Trans. Am microsc. Soc. 101: 84-90

Steudler, P. A., Peterson, B. J. (1984). Contribution of gaseous sulfur from salt marshes to the global sulfur cycle. Nature, Lond. 311: 455-457

Steudler, P. A., Peterson, B. J. (1985). Annual cycle of gaseous sulfur emissions from a New England Spartina alterniflora salt marsh. Atmos. Environ. 19: 1411-1416

Taylor, B., Kiene, R. P. (1989). Microbial metabolism of dimethyl sulfide. In: Saltzman, E. S., Cooper, W. J. (eds.) Biogenic sulfur in the environment. American Chemical Society, Washington, D.C.

Turner, S., Mallin, M. G., Liss, P. S., Harbour, D. S., Holligan, P. M. (1988). The seasonal variation of dimethyl sulfide and dimethylsulfonioproprionate concentrations in nearshore waters. Limnol. Oceanogr. 33: 364-375

Turner, R. E. (1978). Community plankton respiration in a salt marsh estuary and the importance of macrophyte leachates. Limnol. Oceanogr. 23: 442-451

Vairavamurthy A., Andreae, M. O., Iverson, R. L. (1985) Biosynthesis of dimethylsulfide and dimethylpropiothetin by Hymenomonas carterae in relation to sulfur source and salinity variations. Limnol. Oceanogr. 30: 59-70

van Diggelen, J., Rozema, J., Dickson, D. M. J., Broekman, R. (1986). $\beta$-3-dimethysulfonioproprionate, proline, and quaternary ammonium compounds in Spartina anglica in relation to sodium chloride, nitrogen, and sulfur. New Phytol. 103: 573-586

White, H. (1982). Analysis of dimethyl sulfonium compounds in marine algae. J. mar. Res. 40: 529-536

Manuscript first received: December 12, 1991

Revised version accepted: March 10,1992 